\title{
Boekbespreking
}

\section{Lesbrieven voor de fysiotherapeut}

Verhagen AP, Ostelo RWJG, Vet HCW de (ed.). OnderWijs in wetenschap. Lesbrieven voor de fysiotherapeut. Houten: Bohn Stafleu van Loghum; 2002. 176 pagina's. ISBN 9031337641. Prijs $€ 21.90$.

In deze tijd is het overbodig beroepsbeoefenaren, medici of paramedici, nog te wijzen op het belang van evidence-based practice. Fysiotherapeuten hechten ook belang aan een wetenschappelijke onderbouwing van hun vakgebied, en op de hogescholen voor fysiotherapie en in navorming wordt er aandacht aan besteed. Er is een stroom van publicaties losgekomen over dit onderwerp.

In het Nederlands Tijdschrift voor Fysiotherapie zijn sinds 1998 een aantal lesbrieven over methodologie van wetenschappelijk onderzoek gepubliceerd. Deze lesbrieven zijn samen met enkele nieuwe hoofdstukken (nog te publiceren lesbrieven) gebundeld en in het onderhavige boek uitgegeven. $\mathrm{Zij}$ geven een heldere en gestructureerde kijk op de verschillende aspecten van onderzoek, voor zowel het zelf uitvoeren daarvan als het interpreteren van onderzoeksresultaten in relevante wetenschappelijke publicaties.

Door ervaren onderzoekers uit het paramedisch veld wordt gepoogd de lezers een kijkje te laten nemen in de keuken van de wetenschap, om zo op een toegankelijk niveau een aantal onderwerpen te bespreken die niet-wetenschappers (lees: fysiotherapeuten) in staat stellen om zelf conclusies te leren trekken uit wetenschappelijke artikelen. Het is ook bedoeld voor fysiotherapeuten en studenten die onderzoek willen gaan doen.

Dit is op een duidelijke en gestructureerde wijze gedaan. Het boek is helder van opzet. De diverse oude en nieuwe lesbrieven zijn geclusterd in vier delen en worden duidelijk ingeleid. De soms complexe onderwerpen zijn in de verschillende hoofdstukken leesbaar beschreven. Het boek valt uiteen in vier delen.

Onder het motto 'bezint eer ge begint' komen in deel 1 (Inleiding, hoofdstukken 1 t/m 6) ach- tereenvolgens aan de orde de relatie tussen evidence-based practice en wetenschappelijk onderzoek, en de legitimering van beide, het formuleren van een goede onderzoeksvraagstelling, de keuze van het juiste design en de wijze waarop de deelname aan een onderzoek geoptimaliseerd kan worden.

In deel 2 (Metingen) beschrijft men wat samenhangt met het nut van het meten en de kwaliteit van de diverse meetinstrumenten (hoofdstukken $7 \mathrm{t} / \mathrm{m}$ 10). Ingegaan wordt op het wat en hoe van het meten en de relevantie voor de fysiotherapie op zowel functie-, als activiteiten- en participatieniveau. In de hoofdstukken 11 en 12 wordt ingegaan op effectmaten en worden achtereenvolgens statistische significantie en het begrip p-waarde besproken.

Deel 3 (Diagnostiek, hoofdstukken 13 t/m 15) neemt zaken rond de diagnostiek onder de loep. Ook hier worden begrippen als betrouwbaarheid en validiteit weer uitvoerig onder de aandacht gebracht.

In deel 4 (Behandeling, hoofdstukken $16 \mathrm{t} / \mathrm{m}$ 21) staat de vraag 'werkt de behandeling?' centraal. Achtereenvolgens worden randomiseren, blinderen, single case design, kosteneffectiviteit, doel en opzet van systematische reviews en de relatie met richtlijnen toegelicht. Evenals aan het einde van deel 3 (hoofdstuk 15) wordt ook hier in hoofdstuk 21 middels leesopdrachten de mogelijkheid geboden de geïntroduceerde begrippen te oefenen.

De kracht van dit boek zit in de directe toepassing op het fysiotherapeutisch vakgebied. In een aantal hoofdstukken wordt ter illustratie gebruik gemaakt van praktische voorbeelden uit de fysiotherapeutische praktijk. De doelgroep zal er zeker veel aan hebben. Het is echter geen handboek dat alle andere handboeken vervangt. Vanwege het encyclopedische karakter moet dit boek meer beschouwd worden als naslagwerk dan als leerboek. De titel 'OnderWijs in wetenschap' dekt helaas onvoldoende de lading van het boek. Er is geen sprake van een duidelijke definitie en/of afbakening van wat verstaan wordt onder onderwijs in wetenschap.

Omdat het een verzameling reeds gepubliceerde lesbrieven betreft, komen enkele begrip- 
pen, zoals de betrouwbaarheid en validiteit van meetinstrumenten, meerdere malen aan de orde, terwijl andere onderwerpen onderbelicht blijven, zoals dataverwerking en statistiek. Het geeft echter wel een ruim overzicht van aspecten rond wetenschappelijk onderzoek in het vakgebied fysiotherapie. Het is een zeer uitgebreide verzameling van kennis, maar het laat vaardigheden en competenties onderbelicht. Als dit boek bedoeld is als leerboek voor fysiotherapeuten (in opleiding), dan mist het praktische opdrachten die bij een dergelijk onderwerp onontbeerlijk zijn. Er worden weliswaar in twee hoofdstukken zogenaamde leesopdrachten aangeboden, maar deze bieden alleen de mogelijkheid om te stoeien met de geïntroduceerde begrippen. Voor HBO-opgeleide paramedici en HBO-studenten zou enige aandacht voor inleiding in de statistiek op zijn plaats zijn geweest.

Het boek kan desondanks een bijdrage leveren aan het dichten van de kloof tussen alledaags, praktisch paramedisch handelen en wetenschap.

Rob van Bemmel

Fysiotherapeut, bewegingswetenschapper

Coördinator post-HBO Fysiotherapie,

Hogeschool Leiden 